International Conference on Renewable Energies and Power Quality (ICREPQ'11)

Las Palmas de Gran Canaria (Spain), 13th to 15th April, 2011

\title{
Quality of Ashes Produced in the Co-Combustion of Coal and MBM in a Fluidized Bed Reactor
}

\author{
R. Barbosa ${ }^{1}$, N. Lapa ${ }^{1}$, H. Lopes ${ }^{2}$, I. Gulyurtlu², B. Mendes ${ }^{1}$ \\ ${ }^{1}$ UBiA, Faculdade de Ciências e Tecnologia, Universidade Nova de Lisboa, 2829-516 Caparica, Portugal, e-mail: \\ rfb@fct.unl.pt \\ ${ }^{2}$ LNEG, UEZ, Ed. J., Estrada do Paço do Lumiar, 22, 1649-038 Lisboa, Portugal
}

\begin{abstract}
Since the 90's decade there are severe restrictions to the use of MBM, due to BSE. The co-combustion of Meat and Bone Meal (MBM) and coal is a possible energetic valorization route for MBM. However, the chemical and ecotoxicological properties of the ashes produced in this co-combustion process need to be more characterized. In order to evaluate the chemical and ecotoxicological properties of this type of ashes, three combustion tests were performed in a fluidized bed reactor (FBR): 1) combustion of coal; 2) co-combustion of coal and MBM; 3) combustion of MBM. The characterization of the ashes was focused on the following aspects: (1) the bulk content of metals; and (2) the chemical and ecotoxicological characterization of eluates. The ashes were classified according to their ecotoxicity levels based on the French regulation CEMWE. According to Council Decision (CD) 2003/33/EC, all fly ashes need stabilization prior to landfilling, except the $1^{\text {st }}$ cyclone ash produced in the co-combustion test that could be landfilled in a hazardous waste landfill. The bottom ashes were classified as non-hazardous residues. The novelty of this paper is related with two aspects: 1) the use of MBM as co-fuel; and 2) both chemical and ecotoxicological characterization of the ashes produced during the combustion of coal and MBM.
\end{abstract}

\section{Key words}

Combustion, coal, meat and bone meal, ecotoxicity

\section{Introduction}

The replacement of fossil fuels by renewable sources of energy can contribute to improve the environmental performance of the power production and to move forward in the sustainability way [1]. The experience has shown that the availability of alternative fuels can be a serious obstacle for its extensive use for energy production. The use of non-hazardous wastes may be an alternative to biomass, if they are economically unattractive for recycling or if they have a high cost for land filling [2]. Co-firing non-hazardous wastes with coal is, therefore, a subject of great interest for the sustainability of energy production and the reduction of the emissions of fossil greenhouse gases [3]. The use of these wastes for energy is promising if they combine well with other fuels during the conversion process for energy and don't have negative effect on the combustion system, on the ash quality and on the gaseous emissions [4]. The utilization of MBM as animal feedstock was forbidden in 1994, by the European Union, since it was in the origin of the spreading of Bovine Spongiform Encephalopathy (BSE) which can promote the equivalent human disease (Creutzfeldt-Jakob disease). One possible way for the valorization of MBM is its incineration ([5], [6]).

\section{Materials and Methods}

\subsection{FBC, fuels and combustion conditions}

The combustion and co-combustion tests were performed in a bubbling FBR of LNEG/UEZ. Further details of this FBR are shown in Gulyurtlu and Monteiro (1991) [7] and Lapa et al. [8]. Three combustion tests were performed: 1) combustion of coal; 2) co-combustion of coal and MBM (85\% Coal+15\% MBM); 3) combustion of MBM. Each combustion test produced three types of ashes: bottom ashes and two cyclone ashes $\left(1^{\text {st }}\right.$ cyclone and $2^{\text {nd }}$ cyclone ashes). The bottom ashes were collected at the bottom of the FBR and the fly ashes were collected by two containers located at the bottom of each cyclone. The bed material used was cleaned river sand. The fossil fuel used was a bituminous coal from the Colombian mine of El Cerrejón. MBM was produced in slaughter houses of Germany.

\subsection{Bulk characterization of fuels and ashes}


The digestion of the samples was performed according with the USEPA Method 3051A. The following chemical elements were analyzed in the acidic digested samples: As (EN ISO 11969, 1996), Hg (ISO 5666/1, 1983), Cd, Cu, $\mathrm{Ni}, \mathrm{Pb}$ and $\mathrm{Zn}$ (ISO 8288, 1996), Sb, Se, Mo, Ca, Na, K and Ba (AAS flame quantification - APHA et al., 1996), Cr (AAS flame quantification/Method A - ISO 9174, 1990).

2.3. Leaching test, chemical and ecotoxicological characterization of eluates

The ashes were submitted to the leaching test described in the European leaching standard EN 12457-2. The eluates were submitted to same chemical parameters described above for digested samples, plus the following parameters: $\mathrm{pH}, \mathrm{DOC}, \mathrm{CN}^{-}, \mathrm{SO}_{4}{ }^{2-}, \mathrm{F}^{-}$, TDS (APHA/AWWA/WPCF, 1996), $\mathrm{Cl}^{-}$(ISO 9297, 1989), Cr (ISO 9174, 1990), Cr (VI) (NF T90-043, 1988), phenol compounds (ISO 6439, 1990). The eluates were also characterized for the following ecotoxic parameters: a) Luminescence inhibition of the bacteria Vibrio fischeri (ISO 11348-3, 2003); b) Mobility inhibition of the crustacean Daphnia magna (ISO 6341); and c) growing inhibition of the algae Pseudokirchneriella subcapitata (ISO 8692).

\section{Results and discussion}

\subsection{Bulk characterization of fuels}

Table 1 shows the metals bulk composition of the fuels for a set of metals.

Table 1 - Bulk composition of the fuels used in the combustion tests $(\mathrm{mg} / \mathrm{kg} \mathrm{db})$

\begin{tabular}{|c|c|c|}
\hline Parameter & Coal & MBM \\
\hline $\mathrm{Ba}$ & $<3.7$ & 452 \\
\hline $\mathrm{Sb}$ & $<0.07$ & 0.1 \\
\hline $\mathrm{Mo}$ & $<22.4$ & 117 \\
\hline $\mathrm{Se}$ & $<0.2$ & 0.3 \\
\hline $\mathrm{Cu}$ & $<9.4$ & 9.9 \\
\hline $\mathrm{Zn}$ & 36.8 & 94.3 \\
\hline $\mathrm{Cr}$ & 33.5 & $<10.2$ \\
\hline
\end{tabular}

MBM has shown the highest concentrations of the set of heavy metals analyzed. The major differences in the concentration were observed for the parameters $\mathrm{Ba}$, Mo and $\mathrm{Zn}$. The high concentration of $\mathrm{Ba}, \mathrm{Mo}$ and $\mathrm{Zn}$, in MBM, can be explained by the fact that, when consumed by the cattle, they are rapidly transported in blood plasma and accumulated in the bones ([9], [10], [11]). The concentration of $\mathrm{Cr}$ was higher in coal than in MBM. The concentration of $\mathrm{As}, \mathrm{Hg}, \mathrm{Cd}, \mathrm{Pb}$ and $\mathrm{Ni}$ were below the quantification limit $(\mathrm{QL})$ in both fuels.

\subsection{Bulk characterization of ashes}

Table 2 shows the bulk composition of the ashes.

Table 2 - Bulk composition of the bottom, $1^{\text {st }}$ and $2^{\text {nd }}$ cyclone ashes $(\mathrm{mg} / \mathrm{kg} \mathrm{db})$

\begin{tabular}{|c|c|c|c|}
\hline \multirow{2}{*}{ Parameter } & \multicolumn{3}{|c|}{ Bottomashes } \\
\hline & Coal & Coal+MBM & MBM \\
\hline $\mathrm{K}$ & 4,016 & 8,070 & 5,705 \\
\hline $\mathrm{Na}$ & 3,129 & 7,731 & 8,121 \\
\hline $\mathrm{Ca}$ & 48,056 & 18,078 & 129,617 \\
\hline $\mathrm{Cr}$ & 172 & 162 & 133 \\
\hline $\mathrm{Zn}$ & 183 & 28.6 & 128 \\
\hline $\mathrm{Ni}$ & 69.6 & 303 & 43.5 \\
\hline $\mathrm{Cu}$ & $<8.4$ & $<10.4$ & $<93$ \\
\hline $\mathrm{Pb}$ & $<17.4$ & $<18.9$ & $<17.6$ \\
\hline $\mathrm{Cd}$ & 195 & 225 & $<0.70$ \\
\hline $\mathrm{Ba}$ & $<10.4$ & 133 & 3,110 \\
\hline Mo & $<34.8$ & $<37.7$ & $<352$ \\
\hline $\mathrm{Sb}$ & $<0.10$ & $<0.11$ & $<0.11$ \\
\hline $\mathrm{Se}$ & $<0.70$ & $<0.75$ & $<0.70$ \\
\hline $\mathrm{Hg}$ & $<0.42$ & $<0.45$ & $<0.42$ \\
\hline As & 1.4 & 0.89 & $<0.70$ \\
\hline \multirow{2}{*}{ Parameter } & \multicolumn{3}{|c|}{$1^{\text {st }}$ cyclone ashes } \\
\hline & Coal & Coal+MBM & MBM \\
\hline $\mathrm{K}$ & 14,082 & 14,442 & 9,583 \\
\hline $\mathrm{Na}$ & 6,778 & 8,585 & 15,544 \\
\hline $\mathrm{Ca}$ & 15,880 & 51,336 & 238,378 \\
\hline $\mathrm{Cr}$ & 313 & 308 & 572 \\
\hline $\mathrm{Zn}$ & 148 & 178 & 233 \\
\hline $\mathrm{Ni}$ & 298 & 173 & 202 \\
\hline $\mathrm{Cu}$ & 47.8 & 49.9 & 81.1 \\
\hline $\mathrm{Pb}$ & $<26.2$ & $<225$ & 81.1 \\
\hline $\mathrm{Cd}$ & $<9.1$ & $<18.6$ & 177 \\
\hline $\mathrm{Ba}$ & 1,238 & 1,608 & 485 \\
\hline Mo & $<37.8$ & 733 & 140 \\
\hline $\mathrm{Sb}$ & $<0.11$ & $<0.11$ & $<0.11$ \\
\hline $\mathrm{Se}$ & 32 & 1.9 & $<0.73$ \\
\hline $\mathrm{Hg}$ & $<0.45$ & $<0.61$ & $<0.44$ \\
\hline As & 35 & 3.4 & $<0.73$ \\
\hline \multirow{2}{*}{ Parameter } & \multicolumn{3}{|c|}{$2^{\text {nd }}$ cycloneashes } \\
\hline & Coal & Coal+MBM & MBM \\
\hline $\mathrm{K}$ & 14,735 & 17,890 & 27,016 \\
\hline $\mathrm{Na}$ & 6,733 & 9,300 & 23,236 \\
\hline $\mathrm{Ca}$ & 9,185 & 16,463 & 210,427 \\
\hline $\mathrm{Cr}$ & 59 & 292 & 4,800 \\
\hline $\mathrm{Zn}$ & 167 & 234 & 1,495 \\
\hline $\mathrm{Ni}$ & 156 & 158 & 3,828 \\
\hline $\mathrm{Cu}$ & 68.7 & 73.4 & 470 \\
\hline $\mathrm{Pb}$ & 44.7 & 35.6 & 470 \\
\hline $\mathrm{Cd}$ & 19.8 & 19.7 & 5,7 \\
\hline $\mathrm{Ba}$ & 1,086 & 1,428 & 1,782 \\
\hline Mo & 90.3 & 102 & 508 \\
\hline $\mathrm{Sb}$ & $<0.11$ & $<0.11$ & $<0.11$ \\
\hline $\mathrm{Se}$ & 9.7 & 12.9 & $<0.73$ \\
\hline $\mathrm{Hg}$ & $<0.44$ & $<0.75$ & 0.9 \\
\hline As & 6 & 6.2 & 4.8 \\
\hline
\end{tabular}

Coal: Combustion of coal; Coal+MBM: Co-combustion of coal and MBM; MBM: Combustion of MBM 
Generally, the content of metals is higher in the fly ashes. The substitution of coal by MBM has promoted, generally, a higher concentration of metals in the ashes. The concentrations of $\mathrm{Cr}, \mathrm{Ni}$ and $\mathrm{As}$ were similar in the bottom ashes. The $2^{\text {nd }}$ cyclone ashes, especially those produced in the combustion of MBM, have presented the highest concentration of $\mathrm{Cr}, \mathrm{Zn}, \mathrm{Ni}, \mathrm{Cu}$ and $\mathrm{Pb}$, which can be attributed to the lower particle size of the ashes that usually present enrichment in heavy metals due to volatilization/condensation phenomena, especially in presence of high levels of $\mathrm{Cl}$ ([12], [13], [14]). Ba and Mo were also found in high concentrations in the ashes from the combustion tests were MBM was used as fuel. The $1^{\text {st }}$ and $2^{\text {nd }}$ cyclone ashes, produced in the combustion of coal and co-combustion test, have retained As and Se in higher levels than those observed in same type of ashes produced in the combustion of MBM, although the levels were insignificant in the fuels. The same behavior was observed for $\mathrm{Cr}$ and $\mathrm{Cd}$.

\subsection{Leaching behavior of ashes}

\subsubsection{Chemical characterization of the eluates}

Table 3 shows the release of chemical species from the ashes under the leaching test conditions. The concentrations of $\mathrm{Sb}, \mathrm{Zn}, \mathrm{Ni}, \mathrm{Cu}, \mathrm{Pb}, \mathrm{Cd}$ and Phenolic Compounds were below QL. The $\mathrm{pH}$ values of the eluates produced by the bottom ashes were between 8.00 and 11.51, which can be attributed to the high level of alkaline oxides in the bottom ashes. The $\mathrm{pH}$ values of the eluates produced by $1^{\text {st }}$ cyclone ashes were slightly lower (7.44 and 10.50) than those from the bottom ashes. The $\mathrm{pH}$ levels of the eluates from the $2^{\text {nd }}$ cyclone ashes were similar to those from $1^{\text {st }}$ cyclone ashes (7.34 to 11.27$)$. The decrease of $\mathrm{pH}$ levels from the bottom to fly ashes are, probably, associated with the presence of acidic condensates from the flue gases. The concentration of $\mathrm{Cr}(\mathrm{VI})$ was below the QL, except in the eluates produced by the ashes from the combustion of MBM. The concentration of $\mathrm{Cl}^{-}$was, generally, higher in the eluates produced by ashes of co-combustion test and in the combustion of MBM, which can be due to the high concentration of this element in MBM [15]. The concentrations of $\mathrm{F}^{-}$and $\mathrm{SO}_{4}{ }^{2-}$ were higher in the ashes resulting from the combustion tests in which coal was used as fuel. Generally, $\mathrm{Cl}^{-}, \mathrm{F}^{-}, \mathrm{SO}_{4}{ }^{2-}$ were found in higher concentration in fly ashes, which may be associated with the accumulation of particles with high content of these species and more soluble forms [14]. The combustion tests in which MBM was used as fuel have produced ashes with higher concentration of TDS, specially the fly ashes retained in the $2^{\text {nd }}$ cyclone. This fact may be associated with higher contents of soluble species in these particles [14].
Table 3 - Chemical characterization of the eluates produced by the ashes (pH: Sorensen; other species: $\mathrm{mg} / \mathrm{kg} \mathrm{db}$ )

\begin{tabular}{|c|c|c|c|}
\hline \multirow[b]{2}{*}{ Parameter } & \multicolumn{3}{|c|}{ Bottomashes } \\
\hline & Coal & Coal+MBM & $\mathrm{MBM}$ \\
\hline $\mathrm{pH}$ & 11.51 & 9.69 & 8 \\
\hline $\mathrm{SO}_{4}^{-2}$ & 1,580 & 2,897 & 1,863 \\
\hline DOC & 54.2 & 77.4 & $<0.99$ \\
\hline TDS & 4,652 & 4,775 & 11,685 \\
\hline $\mathrm{CN}$ & $<0.13$ & $<0.13$ & $<0.13$ \\
\hline $\mathrm{Cl}^{-}$ & 985 & $<25.0$ & 993 \\
\hline $\mathrm{F}$ & 95.7 & 15 & 79 \\
\hline $\mathrm{K}$ & 52 & 153 & 2986 \\
\hline $\mathrm{Na}$ & 127 & 244 & 2,310 \\
\hline $\mathrm{Ca}$ & 757 & 799 & 113 \\
\hline $\mathrm{Cr}$ & $<0.49$ & $<0.50$ & 2 \\
\hline $\mathrm{CrVI}$ & $<0.49$ & $<0.50$ & 1.6 \\
\hline $\mathrm{Ni}$ & $<0.20$ & $<0.20$ & $<0.20$ \\
\hline $\mathrm{Ba}$ & $<1.6$ & 6 & $<1.6$ \\
\hline Mo & 6.9 & 6.1 & $<0.97$ \\
\hline $\mathrm{Se}$ & 0.19 & $<0.009$ & 0.5 \\
\hline $\mathrm{Hg}$ & $<0.01$ & $<0.01$ & $<0.01$ \\
\hline \multirow[t]{3}{*}{ As } & $<0.03$ & $<0.03$ & $<0.03$ \\
\hline & \multicolumn{3}{|c|}{$1^{\mathrm{s}}$ cycloneashes } \\
\hline & Coal & Coal+MBM & MBM \\
\hline $\mathrm{pH}$ & 105 & 9.61 & 7.44 \\
\hline $\mathrm{SO}_{4}^{-2}$ & 18,925 & 18,734 & 1,786 \\
\hline DOC & 4.2 & 129 & 12.8 \\
\hline TDS & 26,401 & 31,519 & 23,056 \\
\hline $\mathrm{CN}$ & 03 & 0.47 & 0.21 \\
\hline $\mathrm{Cl}$ & 179 & 206 & 1,559 \\
\hline $\mathrm{F}$ & 135 & 108 & 52.3 \\
\hline $\mathrm{K}$ & 650 & 610 & 3,852 \\
\hline $\mathrm{Na}$ & 781 & 958 & 3,782 \\
\hline $\mathrm{Ca}$ & 1,939 & 2,880 & 1,610 \\
\hline $\mathrm{Cr}$ & $<0.51$ & $<051$ & 4.6 \\
\hline $\mathrm{CrVI}$ & $<0.51$ & $<051$ & 1.8 \\
\hline $\mathrm{Ni}$ & $<0.20$ & $<0.20$ & $<0.20$ \\
\hline $\mathrm{Ba}$ & 4.5 & $<1.6$ & 65 \\
\hline Mo & 333 & 18.2 & 46.1 \\
\hline $\mathrm{Se}$ & 29.7 & 0.1 & 0.09 \\
\hline $\mathrm{Hg}$ & $<0.01$ & $<0.01$ & $<0.01$ \\
\hline \multirow[t]{3}{*}{ As } & $<0.03$ & $<0.03$ & $<0.03$ \\
\hline & \multicolumn{3}{|c|}{$2^{\text {nd }}$ cycloneashes } \\
\hline & Coal & Coal+MBM & $\mathrm{MBM}$ \\
\hline $\mathrm{pH}$ & 11.27 & 10.81 & 7.34 \\
\hline $\mathrm{SO}_{4}^{-2}$ & 13,531 & 10,320 & 1,338 \\
\hline DOC & $<1.0$ & 98.9 & 72.3 \\
\hline TDS & 23,955 & 35,098 & 120,056 \\
\hline $\mathrm{CN}$ & $<0.13$ & $<0.13$ & 0.25 \\
\hline $\mathrm{Cl}$ & 103 & 156 & 302 \\
\hline $\mathrm{F}$ & 110 & 95.4 & 641 \\
\hline $\mathrm{K}$ & 341 & 1,033 & 2,430 \\
\hline $\mathrm{Na}$ & 658 & 2,302 & 22,739 \\
\hline $\mathrm{Ca}$ & 2,953 & 1,234 & 6,621 \\
\hline $\mathrm{Cr}$ & $<0.51$ & $<0.52$ & 3.3 \\
\hline $\mathrm{CrVI}$ & $<0.51$ & $<0.52$ & 1.7 \\
\hline $\mathrm{Ni}$ & $<0.20$ & $<0.20$ & 17.2 \\
\hline $\mathrm{Ba}$ & $<1.6$ & 2.7 & 4.1 \\
\hline Mo & 71.3 & 79.7 & 35.5 \\
\hline $\mathrm{Se}$ & 0.82 & 9.6 & 0.28 \\
\hline $\mathrm{Hg}$ & 0.05 & $<0.01$ & $<0.01$ \\
\hline As & 0.12 & $<0.03$ & 0.17 \\
\hline
\end{tabular}


According to CEMWE, the chemical characterization of the eluates has led to the following classification: 1) the ashes from the combustion of coal and co-combustion test were classified as non-ecotoxic; 2) the ashes produced in the combustion of MBM were classified as ecotoxic due to $\mathrm{Cr}(\mathrm{VI})$ (bed ashes), $\mathrm{Cr}$ ( $1^{\text {st }}$ cyclone ashes) and $\mathrm{Ni}$ and $\mathrm{Cr}(\mathrm{VI})\left(2^{\text {nd }}\right.$ cyclone ashes $)$. eluates

\subsubsection{Ecotoxicological characterization of the}

Table 4 shows the Toxicity Units (TU) obtained of the eluates of ashes ( $\mathrm{TU}=100 \% / \mathrm{EC}$, where $\mathrm{EC}$ is the Effective Concentration, in \%).

Table 4 - TU limits defined in CEMWE and TU of the eluates

\begin{tabular}{|c|c|c|c|c|}
\hline \multicolumn{2}{|c|}{ Material/Assay } & D. magna & V.fischeri & $P$. \\
\hline \multicolumn{2}{|c|}{ CEMWElimit } & 10 & 10 & 1000 \\
\hline \multirow{3}{*}{ Bottomashes } & Coal & 1.95 & 4.59 & 4.63 \\
\hline & Coal+MBM & $<1.05$ & $<1.01$ & 1.91 \\
\hline & MBM & $<1.05$ & 2.58 & $<1.05$ \\
\hline \multirow{3}{*}{$\begin{array}{l}1^{\text {s cyclone }} \\
\text { ashes }\end{array}$} & Coal & $<1.05$ & $<1.01$ & $<1.05$ \\
\hline & Coal+MBM & $<1.05$ & $<1.01$ & $<1.05$ \\
\hline & MBM & 157 & 2.35 & $<1.05$ \\
\hline \multirow{3}{*}{$\begin{array}{c}2^{\text {nd }} \text { cyclone } \\
\text { ashes }\end{array}$} & Coal & $<1.05$ & $<1.01$ & 28.6 \\
\hline & $\mathrm{Coal}+\mathrm{MBM}$ & $<1.05$ & $<1.01$ & 131 \\
\hline & MBM & 339 & $<1.01$ & 253 \\
\hline
\end{tabular}

The eluates produced by the ashes have presented low ecotoxicological levels and below the CEMWE limit values. According to CEMWE, the ecotoxicological characterization has led to the classification of all ashes as non-ecotoxic. The bottom ashes produced by combustion of coal have promoted higher ecotoxicity levels probably due to the high pH levels ([16], [14], [17]) or the synergic effect of the factors $\mathrm{pH}$ and solubility of heavy metals. The $2^{\text {nd }}$ cyclone ashes have produced eluates with the highest ecotoxicological levels, especially those produced in the combustion of coal. The $P$. subcapitata was particular sensitive to the eluate produced by the $2^{\text {nd }}$ cyclone ashes from the combustion of coal. Further studies are needed to justify this behavior.

\subsection{Overall ecotoxicological classification of the ashes according to CEMWE}

The ashes produced during the combustion of coal and during the co-combustion test have not shown evidences of ecotoxicity. All ashes produced during the combustion of $\mathrm{MBM}$ are ecotoxic, due to the chemical composition of the eluates.

\subsection{Classification of ashes according with the Council Decision 2003/33/EC}

Table 5 shows the classification of the ashes according the CD 2003/33/EC. All fly ashes require stabilization prior to landfilling, except the $1^{\text {st }}$ cyclone ash produced in the cocombustion test that can be landfilled in a hazardous waste landfill. The bottom ashes produced during the combustion tests were classified as non-hazardous.

Table 5 - Classification of the ashes according to $\mathrm{CD}$ 2003/33/EC

\begin{tabular}{|c|c|c|c|}
\hline \multicolumn{2}{|c|}{ Material/Assay } & Classif. & Dueto.. \\
\hline \multirow{3}{*}{$\begin{array}{l}\text { Bottom } \\
\text { ashes }\end{array}$} & Coal & $\mathrm{N}-\mathrm{H}$ & $\mathrm{Mo}, \mathrm{Se}, \mathrm{F}, \mathrm{SO}_{4}^{2-}, \mathrm{TDS}$ \\
\hline & Coal+MBM & $\mathrm{N}-\mathrm{H}$ & $\mathrm{Mo}, \mathrm{SO}_{4}^{2-}, \mathrm{TDS}$ \\
\hline & MBM & $\mathrm{N}-\mathrm{H}$ & $\mathrm{Cr}, \mathrm{Ni}, \mathrm{CI}, \mathrm{F}, \mathrm{SO}_{4}^{2-}, \mathrm{TDS}$ \\
\hline \multirow{3}{*}{$\begin{array}{c}1^{s} \text { cyclone } \\
\text { ashes }\end{array}$} & Coal & DnA & $\mathrm{MoSe}$ \\
\hline & Coal+MBM & $\mathrm{H}$ & $\mathrm{Mo}, \mathrm{F}$ \\
\hline & MBM & DnA & Mo \\
\hline \multirow{3}{*}{$\begin{array}{c}2^{\text {nd }} \text { cyclone } \\
\text { ashes }\end{array}$} & Coal & DnA & Mo \\
\hline & Coal+MBM & DnA & $\mathrm{Mo}, \mathrm{Se}$ \\
\hline & MBM & DnA & $\mathrm{Mo}, \mathrm{Ni}, \mathrm{F}, \mathrm{TDS}$ \\
\hline
\end{tabular}

N-H: Non Hazardous; $\mathrm{H}$ : Hazardous; DnA: Deposition not Allowed

\section{Conclusions}

The substitution of coal by MBM produced ashes with higher content of heavy metals but with similar leaching rates. According to CEMWE the ashes produced during the combustion of coal and co-combustion test didn't show evidences of ecotoxicity. All ashes produced during the combustion of MBM are ecotoxic due to the chemical composition of the eluates. According to the $\mathrm{CD}$ 2003/33/EC, all fly ashes need stabilization prior to landfilling, except the $1^{\text {st }}$ cyclone ash produced in the cocombustion test that was classified as hazardous residues. The bottom ashes were classified as non-hazardous residues. Further studies related with the possible valorization of the ashes are needed.

\section{Acknowledgement}

The authors would like to acknowledge the Fundação para a Ciência e a Tecnologia do Ministério da Ciência, Tecnologia e Ensino Superior for having funded a $\mathrm{PhD}$ grant that supported the research of one of the authors.

\section{References}

[1] J. Morais, N. Lapa, R. Barbosa, A. Santos, B. Mendes, J. F. Santos Oliveira, "Environmental and socio-economic assessment of co-combustion of coal, biomass and nonhazardous wastes in a full scale power plant", in Proceedings of the International Conference and Exhibition on Bioenergy: Bioenergy: Challenges and Opportunities, April 6th - 9th, Universidade do Minho, Guimarães (2008), Portugal.

[2] A. A. Khan, W. Jong de, P. J. Jansens, H. Spliethof, "Biomass combustion in fluidized bed boilers: Potential 
problems and remedies”, Fuel Processing Technology, 2009, 90, 21-50

[3] B. Arias, C. Pevida, F. Rubiera, J. J. Pis, "Effect of biomass blending on coal ignition and burnout during oxy-fuel combustion", Fuel, 2008, 87, 2753-2759

[4] M. H. Lopes, P. Abelha, N. Lapa, J.S. Oliveira, I. Cabrita, I. Gulyurtlu, "The behaviour of ashes and heavy metals during the co-combustion of sewage sludges in a fluidised bed", Waste Management, 2003, 23, 859-870

[5] E. J. Cummins, K. P. McDonnell, S. M. Ward, "Dispersion modelling and measurement of emissions from the cocombustion of meat and bone meal with peat in a fluidised bed", Bioresource Technology, 2006, 97, 903-913

[6] National Agricultural Biosecurity Center Consortium, USDA APHIS Cooperative Agreement Project, Carcass Disposal Working Group, "Carcass Disposal: A Comprehensive Review", Kansas State University (2004), USA

[7] I. Gulyurtlu, A. P. Monteiro, "Memória descritiva do leito fluidizado LF30", LNETI/DEC, Lisboa (1991)

[8] N. Lapa; R. Barbosa; M. H. Lopes, B. Mendes, P. Abelha, I. Gulyurtlu, J. Santos Oliveira, "Chemical and ecotoxicological characterization of ashes obtained from sewage sludge combustion in a fluidised-bed reactor. Journal of Hazardous Materials, 2007, 147, 175-183

[9] World Health Organization (Water Sanitation and Health), "Molybdenum in Drinking-water Background document for development of WHO Guidelines for Drinking-water Quality", WHO/SDE/WSH/03.04/11 (2003a)

[10] World Health Organization (Water Sanitation and Health) "Zinc in Drinking-water Background document for development of WHO Guidelines for Drinking-water Quality", WHO/SDE/WSH/03.04/17 (2003b)

[11] World Health Organization (Water Sanitation and Health), "Barium in drinking-water; Background document for development of WHO Guidelines for Drinking-water Quality", WHO/SDE/WSH/03.04/76 (2004)

[12] H. Lopes, I. Gulyurtlu, P. Abelha, Abelha T. Abelha, D. Salema, M. Freire, R. Pereira, I. Cabrita, "Particulate and $\mathrm{PCDD} / \mathrm{F}$ emissions from coal co-firing with solid biofuels in a bubbling fluidised bed reactor", Fuel, 2009, 88, 2373-2384

[13] M. Van de Velden, R. Dewil, J. Baeyens, L. Josson, P. Lanssens, "The distribution of heavy metals during fluidized bed combustion of sludge (FBSC)" Journal of Hazardous Materials, 2008, 151, 96-102

[14] R. Barbosa, N. Lapa, D. Boavida, H. Lopes, I. Gulyurtlu, B. Mendes, "Co-combustion of coal and sewage sludge: Chemical and ecotoxicological properties of ashes, Journal of Hazardous Materials, 2009, 170, 902-909

[15] I. Gulyurtlu, P. Abelha, H. Lopes, A. Crujeira, I. Cabrita, "Considerations on valorization of biomass origin materials in co-combustion with coal in fluidized beds", Third International Conference on Clean Coal Technologies for our Future, 15-17 May, Sardinia (2007), Italy

[16] I. Lopes, F. Gonçalves, A. M. V. M. Soares, R. Ribeiro, "Discriminating the ecotoxicity due to metals and to low $\mathrm{pH}$ in acid mine drainage", Ecotoxicol. Environ. Saf. (1999), 44, 207-214

[17] R. Barbosa, "Chemical and ecotoxicological characterizations of bottom and fly ashes resulting from the co-combustion of sewage sludge and coal", MSc thesis, FCT/UNL, Lisboa (2005), Portugal 